\title{
ENVIRONMENTAL PROBLEMS OF MANIPUR
}

\author{
Arambam Sophia*, Mayanglambam Sarda Devi*** \\ * Manipur University, Department of Economics, Canchipur, Manipur, India \\ ** Kakching Khunou College, Department of Economics, Kakching Khunou, Manipur, India \\ corresponding author: Arambam Sophia, e-mail: asophiachanu@gmail.com
}

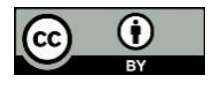

This work is licensed under a

Creative Commons Attribution 4.0

$\underline{\text { International License }}$
Review paper

Received: November $12^{\text {th }}, 2019$

Accepted: January $26^{\text {th }}, 2020$

HAE-1928

https://doi.org/10.33765/thate.10.4.4

\begin{abstract}
The issue of environment versus human activity has become one of the most common global topics. Global warming, greenhouse effect, air pollution, land and water pollution are all results of human activity. Human behaviour lies at the root of both conservation and environmental damage. The rapid growth of population and economic development are some of the greatest threats to the environment through the expansion and intensification of agriculture, uncontrolled growth of urbanization and industrialization, and the destruction of natural habitats. The paper seeks to study the unique features of Manipur, a pristine land situated in the North-East corner of India which is noted for its rich biodiversity, abundance of medicinal plants with various healing properties and yet it is facing the threat of environmental degradation and pollution. It is mainly rapid population growth, unplanned urbanization in urban areas, lack of awareness about environmental issues, poverty and Jhuming cultivation practices in the hills that have led to environmental damage, with its concomitant effects on human development, for it is ultimately the people of the state who have to suffer the effects of environmental damage. The paper gives a broad picture of the abundant green resources and unique fauna of Manipur and the environmental problems that threaten its biodiversity.
\end{abstract}

Keywords: environment, urbanization, population, pollution, medicinal plants, Jhuming

\section{INTRODUCTION}

Environment versus human activity has become one of the most important global current issues. Actually, human beings are the main causes of environmental degradation as well as all the environmental problems that the world faces today. Global warming, greenhouse effect, air pollution, and so on - all these are the results of human activity. Human behaviour lies at the root of both conservation and environmental damage.

The rapid growth of population and economic development are some of the greatest threats to the environment through the expansion and intensification of agriculture, uncontrolled growth of urbanization, the destruction of natural habitats, and imperatives of industrialization etc. Economic development is very essential for the human wellbeing and for 
the development of nations, but is often a source of harmful environmental pollution. The World Commission on Environment and Development (1987) defined sustainable development as development that meets the needs of the present without compromising the ability of future generations to meet their own needs. It contains within it two key concepts: (a) the concept of "needs", in particular the essential needs of the world's poor, to which overriding priority should be given and (b) the idea of limitations imposed by the state of technology and social organization on the environment's ability to meet present and future needs [1].

There are two concepts of sustainability; firstly, the economist's world view of sustainability is concerned about the long term constancy of economic output, income, or consumption and secondly, the ecologist's or biologist's concept of sustainability relates to long term preservation of biosphere, i.e., the sustenance of human population and biodiversity conservation in a given geographical area/region, endowed with limited natural resources [2]. The concept of sustainable development also came into being, which brings environment and development together.

Environmental degradation compromises the security of life of the future generation and adversely affects human development of the current generation too. Health hazards are created by environmental pollution and the depletion of exhaustible natural resources affects people's livelihoods at present and in the future too. The pollution of the environment is also responsible for the emergence or resurgence of many diseases, like malaria, dengue, encephalitis and other vector-borne diseases. Increase in greenhouse gases (GHGs), with its resultant global warming, pollution of water bodies, increased dependence on pesticides and many other problems now pose dilemmas in most countries. "Two of the environmental indicators viz., access to safe drinking water and sanitation are closely linked with two of the very important human development indicators viz., infant mortality rate and life expectancy" [3]. Pollution of air, water and land combined with poverty and unhygienic conditions especially in human settlements like slums etc. contribute to reduction in life expectancy and increase in infant mortality. Larger population leads to more poverty and worsens the environment, creating a vicious cycle.

Developed industrialist countries of the world have contributed more to environmental degradation than underdeveloped countries because they emit more greenhouse gases through their industrial activities. In the underdeveloped countries; deforestation, for example, is only partly caused by local demand for agricultural land or construction materials. Fisheries, mineral deposits, energy supplies, and bio-diversity resources are harvested in developed and developing countries alike; however, the preferences and demands of the world's richest countries largely determine the scale and intensity of resource exploitation. It has been emphasized that it is in fact the developed countries of the world that have largely driven climate change which threatens wellbeing of human beings and endangers ecosystem and biodiversity. Although developed countries represent only $20 \%$ of the world's population, they have generated $80 \%$ of GHGs (greenhouse gases) emission [4]. Global warming is rising global temperatures and melting the glaciers and snows. This will ultimately have a devastating impact on our planet.

Taking note of increasing environmental damage of unregulated human activities, economic and environmental groups came together to debate about the dangers of these consequences. Various agreements were signed like the "Kyoto Protocol", an agreement whereby the industrialized countries agreed to reduce their collective emissions of six greenhouse gases by $5.2 \%$ compared to the year 1990, averaged over the period of 2008 - 2012, "Montreal Protocol" which is an international treaty designed to protect the ozone layer by phasing out the production of a number of substances believed 
to be responsible for ozone depletion, signed on September 16, 1987 and entered into force on January 1, 1989 followed by a first meeting in Helsinki, May 1989. It has since undergone many revisions. The belief is that if the international agreement is adhered to, the ozone layer might recover by 2050, "Stockholm Conference", an international conference held in Stockholm in 1972 which addressed various environmental concerns: The threat posed to the atmosphere by chlorofluorocarbons (CFCs); acidification of lakes and forests in North America and Europe due to acid rain, etc. are some examples.

The paper brings out the unique nature of Manipur's endemic flora and fauna and highlights its potential as well as its problems. It also tries to see how environmental problems and damages have seeped in eroding its rich biodiversity potential. The paper describes the causes of and the extent of environmental damage in Manipur.

Given available data from secondary sources, the paper tries to analyse the data to make meaningful conclusions from it. It relies on secondary sources of data from government reports and publications, books, journals and other online articles etc.

In this regard, one major problem that came up is the lack of up-to-date data for government publications. But the study will highlight the importance of Manipur's unique heritage and focus on the necessity of environment conservation and sustainable development.

\section{MANIPUR}

Manipur, literally meaning "land of jewel", is a beautiful land-locked land with a valley in the centre surrounded by many hill ranges. It is a pristine land situated in North-East India. It has an area of $22,327 \mathrm{~km}^{2}$ which is $0.68 \%$ of the country's geographical area. It shares international border with Myanmar and lies between the latitudes of $23^{\circ} 50^{\prime} \mathrm{n}$ and $25^{\circ} 42^{\prime} \mathrm{n}$ and the longitudes of $92^{\circ} 59^{\prime} \mathrm{e}$ and $94^{\circ} 46^{\prime} \mathrm{e}$.
Manipur was initially composed of 9 districts, but with recent subdivision and bifurcation it has now 14 districts in all. The land is home to various ethnic groups and communities, like the Meiteis (majority ethnic community mainly settled in the valley), the Meitei Pangals (Manipuri Muslims), and various Scheduled Tribes and Scheduled Castes communities. In accordance with The Scheduled Castes and Scheduled Tribes Orders (Amendment) Act, 1976, there are 29 Scheduled Tribes and 7 Scheduled Castes communities in Manipur.

\section{MANIPUR'S UNIQUE FAUNA AND FLORA}

Manipur State falls in the region of IndoBurma biodiversity hotspot, which is known to be one of the most threatened biodiversity hotspot due to the high rate of resource exploitation and habitat loss.

The Hoolock Gibbon, the Sloe Loris, the Clauded Leopard, the Spotted Linshang, Mrs. Hume's Barbacked Pheasant, Blyths Tragopan, Burmese Pea-fowl, four different species of hornbills and the Salamader known as Lengwa, which is found at the foothills of Siroi hills, form only a small part of the rich fauna of Manipur (from the official website of Manipur State, India). The most unique of Manipur's fauna is the Sangai, brow antlered deer. The floating mass of vegetation on Loktak Lake, the Phumdi sustains small herds of this endemic deer. The sanctuary of the deer is now the only floating national park in the world, named Keibul Lamjao. The number of Sangai had decreased due to the continuous inundation and flooding by high waters of the artificial reservoir of the National Hydroelectric Power Corporation, Loktak, as well as by ecological change of the Loktak Lake. There were also threats on its life from poachers. A major source of pollution of the Loktak Lake on which the Phumdi floats is the man-made sometimes hazardous wastes and debris brought down by rivers which drain into the lake. The deer was believed to be almost 
extinct by 1950. However, in 1953 six heads of the Sangai were found hovering at its natural habitat. Since then, the State Government has taken serious and positive measures for the protection of this rare and endangered species. The number of endangered Sangai deer found in Manipur has increased from 204 in 2013 to 260 , according to the census conducted in March 2016 jointly by Wildlife Wing, Forest department, State government, Manipur University and Wildlife Institute of India [5].

The Shirui Hills of Manipur is known for a unique species of land-lily, the Shirui Lily which grows at a height of about $2590,8 \mathrm{~m}$ above sea level. It was declared as the State Flower of Manipur in 1989. The state is also a bio reserve of international significance, with proliferation of diverse herbs, fruits, vegetables, medicinal, aromatic and ornamental plants, forests, etc.

An abundance of medicinal plants are growing in Manipur. Various authors have already explored the uses and applications of such medicinal plants of Manipur [6 - 13]. They are used in the treatment of various illnesses, like diabetes, liver problems, skin problems, blood pressure, piles, rheumatism, gout, stone case, cancer, asthma, cosmetics, etc. Nearly 1200 species of medicinal plants are reported from the state [14]. Some of the plant species are in critical conditions due to deforestation, overexploitation, various activities of human population for their survival and other developmental activities, such as agriculture, urbanization etc., as a result of which the rich habitats are gradually depleting day by day. Hence the need arises for conservation [10].

One positive aspect related to Meitei (majority ethnic community of Manipur) religion is the preservation of forest patches known as sacred groves by incorporating them with religion and nature worship. The traditional religion of the Meiteis forbade the destruction of such sacred groves, which are believed to be the abode of their revered sylvan deities, the Umanglais (Lai: God or Goddess, Umang: forest). This belief has sustained the preservation of such sacred groves thereby saving the trees in such groves.

They also preserve certain plants linked with their ritual and beliefs. Disposal of waste products, urination, garbage etc. are not allowed near the vicinity of these trees/plants as it is believed that these will anger the deity and bring bad omen to the family. A study of these sacred plants reveals that they have more or less healing powers and have been used for medicinal purposes. Practice of plucking or cutting only on specific days and prohibition of cutting during the night time may be a form of conservation of these plants from over exploitation and destruction to preserve these plants for posterity. This preservation has saved many trees and plants from extinction [15]. But due to modern values replacing traditional beliefs thereby leading to change in ideas and beliefs, there is increasing overexploration of land, and because of such over exploitation, "many of the sacred groves are going to disappear" [16].

"Among the 166 inventoried sacred groves in the four districts of Manipur located in valley areas, only a few (11\%) are well preserved, while most are partly threatened (58\%) and others threatened $(31 \%)$ due to various anthropogenic pressures such as developmental activities, urbanization and population explosion. Degradation of scared groves not only signifies loss of species-rich relict vegetation, but also the rich cultural heritage of the region" [17].

About 1200 rare species of medicinal plants growing in different parts of Manipur are facing the threat of gradual disappearance, in the absence of organised system of care and scientific intervention [16]. Figure 1 shows the various uses of these medicinal plants in percentage.

\section{CLIMATE CHANGES IN MANIPUR}

Manipur's temperature has also changed. Rainfall is erratic and uncertain. Droughts 
alternate with floods, hot season is becoming longer than the cold season and in winter, it has become less cold and the winter temperatures are not as freezing cold as before. There is now drought during the winter season (i.e. December to March).

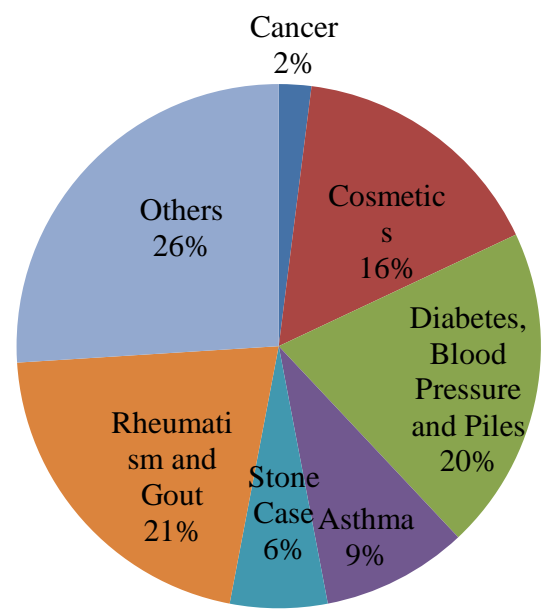

Figure 1. Percentage of plants used as cosmetics and as medicines for various illnesses [11]

The dataset of surface temperature variation observed during 1954 - 2011 shows an increasing trend in both the minimum and maximum temperatures. The maximum temperature has increased from $26.5{ }^{\circ} \mathrm{C}$ to $27.3{ }^{\circ} \mathrm{C}$ while the minimum temperature has increased from $13.8{ }^{\circ} \mathrm{C}$ to $15.3{ }^{\circ} \mathrm{C}$. The night temperatures have also risen. Seasonal variability of minimum and maximum surface temperatures in Manipur was from $4{ }^{\circ} \mathrm{C}$ (January) to $21.5{ }^{\circ} \mathrm{C}$ (July) and $21.5{ }^{\circ} \mathrm{C}$ (January) to $28.9{ }^{\circ} \mathrm{C}$ (July) respectively. Some parts of the state have experienced increases in both maximum and minimum temperatures of $\geq 1.75^{\circ} \mathrm{C}$ and $\geq 1.5^{\circ} \mathrm{C}$, respectively in the last 100 years. For rainfall, daily precipitations datasets were analysed for the 57 years from 1954 to 2011. Annual rainfall quantum varies from 956.5 to $2269.9 \mathrm{~mm}$, and period of raining days has extended from the monsoon months i.e. June - October to pre-monsoon months like April and May. The relative humidity of the state has also increased. High rate of humidity and increased temperatures are favourable for mosquitoes and vector borne diseases like malaria, dengue, etc. The relative humidity of the state was $74.22 \%$ during 1969 to 2011. It has reached $80 \%$ during the night time [18].

Manipur, which enjoyed moderate and pleasant temperatures throughout the years, continues to record soaring temperature in the last decades. On April 14, 1999, the Meteorological Observatory Unit in Imphal recorded a temperature of $36{ }^{\circ} \mathrm{C}$, which was the maximum since 1952. On $21^{\mathrm{st}}$ April, 2014, the unit recorded $35.6{ }^{\circ} \mathrm{C}$, the highest since 1999 (22 April, 2014, Times of India). On $21^{\text {st }}$ May, 2015, Manipur had another record of soaring temperature. Moreh Town in Chandel District records $39.4{ }^{\circ} \mathrm{C}$, the highest in the history of Manipur (Mercury Hits $39{ }^{\circ} \mathrm{C}$, Sangai Express, 21 May 2105) [19].

\section{LAND USE PATTERN OF MANIPUR}

Table 1 below gives the land use pattern of Manipur. In Manipur, lands under permanent pasture and other grazing lands, lands under miscellaneous tree crops and groves, culturable wasteland, current fallow lands and fallow lands other than current fallows constituted less than one percent of the entire reporting area for land utilization, Moreover, about $1 \%$ of the reporting land is not available for cultivation. On the contrary, at the all India level, these lands constitute more than $31 \%$ of the total reporting area for land utilization. It portrays that Manipur has a potential in exploiting forest lands prudently for various kinds of land development for sustainable agriculture (enhancing food production without destroying the environment, incorporating all dimensions of sustainable development, namely environmental, economic and social) as well as other suitable development activities [20]. 
Table 1. Land use pattern (Manipur and India) [21, 22]

\begin{tabular}{|c|c|c|c|c|c|c|c|c|c|c|}
\hline \multirow{2}{*}{\multicolumn{2}{|c|}{$\begin{array}{l}\text { State } \\
\text { Years }\end{array}$}} & \multicolumn{5}{|c|}{ Manipur } & \multicolumn{4}{|c|}{ India } \\
\hline & & 1 & $\begin{array}{c}1999- \\
2000\end{array}$ & $\begin{array}{l}2004- \\
2005\end{array}$ & $\begin{array}{c}2009- \\
2010\end{array}$ & $\begin{array}{l}2014- \\
2015\end{array}$ & $\begin{array}{c}1999- \\
2000\end{array}$ & $\begin{array}{l}2004- \\
2005\end{array}$ & $\begin{array}{c}2009- \\
2010\end{array}$ & $\begin{array}{c}2014- \\
2015\end{array}$ \\
\hline \multicolumn{2}{|c|}{ Geographical area, x 1000, ha } & 2 & 2233 & 2233 & 2233 & 2233 & 328726 & 328726 & 328726 & 328726 \\
\hline \multicolumn{2}{|c|}{$\begin{array}{l}\text { Reporting area for land utilization } \\
\text { (RAFLU), x } 1000, \text { ha }\end{array}$} & 3 & 1927 & 1967 & 1997 & 2117 & 305016 & 305578 & 307408 & 307818 \\
\hline \multicolumn{2}{|c|}{ Forests, $\%$ of RAFLU } & 4 & 87.85 & 86.07 & 86.52 & 80.25 & 22.67 & 22.79 & 23.28 & 23.32 \\
\hline \multicolumn{2}{|c|}{$\begin{array}{l}\text { Not available for cultivation, } \% \text { of } \\
\text { RAFLU }\end{array}$} & 5 & 1.40 & 1.37 & 1.35 & 1.27 & 14.46 & 13.89 & 14.09 & 14.25 \\
\hline \multirow{4}{*}{$\begin{array}{l}\text { Other } \\
\text { unculti } \\
\text { vated } \\
\text { land } \\
\text { excludi } \\
\text { ng } \\
\text { fallow } \\
\text { land }\end{array}$} & $\begin{array}{c}\text { Permanent pastures and } \\
\text { other grazing lands, \% of } \\
\text { RAFLU }\end{array}$ & 6 & 0.05 & 0.05 & 0.05 & 0.05 & 3.56 & 3.42 & 3.36 & 3.33 \\
\hline & $\begin{array}{c}\text { Land under miscellaneous } \\
\text { tree crops and groves (not } \\
\text { included in net area sown), } \\
\% \text { of RAFLU }\end{array}$ & 7 & 0.31 & 0.31 & 0.30 & 0.28 & 1.22 & 1.11 & 1.05 & 1.01 \\
\hline & $\begin{array}{l}\text { Culturable wasteland, } \\
\% \text { of RAFLU }\end{array}$ & 8 & 0.05 & 0.05 & 0.05 & 0.05 & 4.50 & 4.34 & 4.21 & 4.05 \\
\hline & $\begin{array}{c}\text { Total (row } 6 \text { to } 8 \text { ), \% of } \\
\text { RAFLU }\end{array}$ & 9 & 0.41 & 0.41 & 0.40 & 0.38 & 9.28 & 8.88 & 8.62 & 8.39 \\
\hline \multirow{3}{*}{$\begin{array}{l}\text { Fallow } \\
\text { lands }\end{array}$} & $\begin{array}{c}\text { Fallow lands other than } \\
\text { current fallows, \% of } \\
\text { RAFLU }\end{array}$ & 10 & 0 & 0 & 0 & 0 & 3.37 & 3.49 & 3.53 & 3.60 \\
\hline & $\begin{array}{c}\text { Current fallows, } \% \text { of } \\
\text { RAFLU }\end{array}$ & 11 & 0 & 0 & 0 & 0 & 4.94 & 4.74 & 5.21 & 4.90 \\
\hline & $\begin{array}{l}\text { Total (row }(10+11) \\
\% \text { of RAFLU }\end{array}$ & 12 & 0 & 0 & 0 & 0 & 8.30 & 8.23 & 8.73 & 8.51 \\
\hline \multicolumn{2}{|c|}{ Net area sown, $\%$ of RAFLU } & 13 & 10.33 & 12.10 & 11.72 & 18.09 & 46.25 & 46.20 & 45.27 & 45.52 \\
\hline
\end{tabular}

\section{FOREST COVER IN MANIPUR}

Table 2 presents district-wise forest cover areas. We see that there has been decline in forest cover from 2017 assessment for all the districts of Manipur. The greatest decline in forest cover is seen in Churachandpur and Tamenglong districts in Manipur with losses greater than $100 \mathrm{~km}^{2}$.

Table 2. District-wise forest cover (2019) assessment [14]

\begin{tabular}{|c|c|c|c|c|c|c|c|c|}
\hline District & $\begin{array}{c}\text { Geographical } \\
\text { area } \\
\left(\mathrm{km}^{2}\right)\end{array}$ & $\begin{array}{c}\text { Very } \\
\text { dense } \\
\text { forest } \\
\left(\mathrm{km}^{2}\right)\end{array}$ & $\begin{array}{c}\text { Mod. dense } \\
\text { forest } \\
\left(\mathrm{km}^{2}\right)\end{array}$ & $\begin{array}{c}\text { Open } \\
\text { forest } \\
\left(\mathrm{km}^{2}\right)\end{array}$ & $\begin{array}{c}\text { Total } \\
\left(\mathrm{km}^{2}\right)\end{array}$ & $\begin{array}{c}\text { \% of } \\
\text { Geographical } \\
\text { area } \\
\left(\mathrm{km}^{2}\right)\end{array}$ & $\begin{array}{c}\text { Change } \\
\text { from 2017 } \\
\left(\mathrm{km}^{2}\right)\end{array}$ & $\begin{array}{c}\text { Scrub } \\
\left(\mathrm{km}^{2}\right)\end{array}$ \\
\hline Bishnupur & 496 & 0.00 & 0.99 & 20.51 & 21.50 & 4.33 & -0.50 & 2.00 \\
\hline Chandel & 3,313 & 10.76 & 950.42 & $1,902.17$ & $2,860.35$ & 86.43 & -43.65 & 139.09 \\
\hline Churachandpur & 4,570 & 41.92 & $1,614.50$ & $2,263.09$ & $3,919.51$ & 85.77 & -249.49 & 164.67 \\
\hline Imphal East & 709 & 0.00 & 60.90 & 213.36 & 274.26 & 38.68 & -3.74 & 15.00 \\
\hline Imphal West & 519 & 0.00 & 15.66 & 36.09 & 51.75 & 9.97 & -2.25 & 9.22 \\
\hline Senapati & 3,271 & 270.75 & 744.46 & $1,121.37$ & $2,136.58$ & 65.32 & -47.42 & 287.56 \\
\hline Tamenglong & 4,391 & 388.90 & $1,726.75$ & $1,728.79$ & $3,844.44$ & 87.55 & -108.56 & 166.67 \\
\hline Thoubal & 514 & 0.00 & 2.00 & 68.76 & 70.76 & 13.77 & -2.24 & 11.14 \\
\hline Ukhrul & 4,544 & 192.94 & $1,270.61$ & $2,201.20$ & $3,664.75$ & 80.65 & -41.25 & 386.12 \\
\hline Total & 22,327 & 905.27 & $6,386.29$ & $9,553.34$ & $16,846.90$ & 75.46 & -499.10 & $1,181.47$ \\
\hline
\end{tabular}




\section{ENVIRONMENTAL DEGRADATION IN MANIPUR}

Coming to the problem of environmental degradation in Manipur, the following factors may be analysed as main causes of environmental degradation in Manipur:

- rapid growth of population,

- uncontrolled growth of urbanization,

- expansion and intensification of agriculture, mainly through shifting cultivation practices,

- destruction of natural habitats, and

- large scale development projects (dam, industries etc.).

\section{Growth of population}

The rapid growth of population is one of the greatest threats to the environment in Manipur. During fifty years' time, decennial population growth rate of Manipur has been increasing at a fast rate; it is higher than all India averages. The following Table 3 shows the growth of population Manipur vis-a-vis India during 1951 to 2011 . There is tremendous population explosion in Manipur. The decennial growth of population is much higher than that of all India, in all the census years except 1951.

According to 2011 census, Manipur has a total population of $2,855,744$. The population has grown by about $24 \%$ during the decade 1991 to 2001. Manipur valley is a thickly populated area with a density of 631 persons per $\mathrm{km}^{2}$ as against 44 persons per $\mathrm{km}^{2}$ in the hills according to 2001 census [16]. As per 2011 census, the average density of the state is 128 persons per $\mathrm{km}^{2}$ as against the all India average of 382 persons per $\mathrm{km}^{2}$.

\section{Uncontrolled growth of urbanization}

Urban population in Manipur is growing at a fast rate leading to substantial increase in generation of solid waste in both absolute and per capita terms. There is increasing expansion of commercial activities in Khwairamband
Bazaar (main market of Manipur), Singjamei Bazaar, Lamlong Bazaar and Kwakeithel Bazaar. We see wastes piling up in every corner, with Imphal municipality hardly functioning for days and months so that even mere skeleton municipal services are not available; a distinct sign of institutional weakness. The same picture is seen at Tamenglong Bazaar, Chandel Bazaar, Moreh Bazaar, and Ukhrul Bazaar. The Table 4 shows the growth of urbanisation in Manipur.

Urban population as a percentage to total population has been growing from 26.42 in $1981,27.52 \%$ in $1991,25.11 \%$ in 2001 , and $29.21 \%$ in 2011. The highest percentage obtained in 2011, with urban population being $29.21 \%$ of the total population. The decennial growth rate has been suddenly increasing from 108.95 in 1971 to 165.36 in 1981 , but declining in 1991 and 2001. In the census year 2011, it has been increasing to 44.83. But the highest increase is the unprecedented spurt of $2267.07 \%$ in 1961 over 1951 mainly because of the unexplained decline of urbanization growth by about $97.13 \%$ in 1951 over 1941 . In addition to pressures of population growth and urbanization, human activity is the main cause of environmental degradation and all the environmental problems they face.

\section{Expansion and intensification of agriculture, mainly through shifting cultivation practices}

Shifting cultivation or Swidden agriculture also known as Jhumming cultivation is widely practiced in Manipur. It is a technique of rotational farming whereby land is cleared for cultivation by burning and then after the crops are cultivated, the land is left to regenerate for a few years until it is time to grow crops again. It is also called slash and burn agriculture.

Agriculture is the main occupation and largest source of livelihood for more than $70 \%$ of the total population of the state. Forest exploitation for shifting cultivation and other forest products is significant in the state. 
Table 3. Growth of population in Manipur vis-a-vis India during 1951 to 2011 [23 - 25]

\begin{tabular}{|c|c|c|c|c|c|c|c|c|}
\hline \multirow{2}{*}{$\begin{array}{c}\text { Census } \\
\text { year }\end{array}$} & \multirow{2}{*}{$\begin{array}{c}\text { Manipur } \\
\text { total } \\
\text { population }\end{array}$} & \multirow{2}{*}{$\begin{array}{c}\text { Manipur } \\
\text { area } \\
\left(\mathrm{km}^{2}\right)\end{array}$} & \multirow{2}{*}{$\begin{array}{c}\text { India } \\
\text { total } \\
\text { population }\end{array}$} & \multirow{2}{*}{$\begin{array}{l}\text { India area } \\
\left(\mathrm{km}^{2}\right)\end{array}$} & \multicolumn{2}{|c|}{$\begin{array}{c}\text { Decennial growth rate } \\
\text { of population, }(\%)\end{array}$} & \multicolumn{2}{|c|}{$\begin{array}{l}\text { Population density } \\
\left(\text { people } / \mathrm{km}^{2}\right)\end{array}$} \\
\hline & & & & & Manipur & India & Manipur & India \\
\hline 1951 & 577,635 & 22,347 & $361,088,090$ & $3,287,263$ & 12.80 & 13.31 & 26 & 117 \\
\hline 1961 & 78 & 47 & 439, & & 5.04 & & 35 & 142 \\
\hline 1971 & $1,072,753$ & 22,327 & $548,159,652$ & 28 & 37.53 & 24.8 & 48 & 177 \\
\hline 1981 & $1,420,953$ & 22,327 & $683,329,097$ & $3,287,263$ & 32.46 & 24.66 & 64 & 216 \\
\hline 1991 & $1,837,149$ & 22,327 & $846,421,039$ & $3,287,263$ & 29.29 & 23.85 & 82 & 267 \\
\hline 2001 & $2,293,896$ & 22,327 & $1,028,737,436$ & $3,287,263$ & 24.86 & 21.34 & 103 & 325 \\
\hline 2011 & $2,855,744$ & 22,327 & $1,210,193,422$ & $3,287,263$ & 24.50 & 17.70 & 128 & 382 \\
\hline
\end{tabular}

Notes:

a) Manipur's figure includes estimated population of Paomata, Mao Maram and Purul sub-divisions of Senapati District of Manipur for 2001.

b) For working out the density of India and Jammu \& Kashmir the entire area and population of those portions of Jammu \& Kashmir which are under illegal occupation of Pakistan and China have not been taken into account.

Table 4. Urbanization in Manipur, 1951 - 2011 census [23]

\begin{tabular}{|c|c|c|c|c|c|c|c|}
\hline \multirow{3}{*}{$\begin{array}{l}\text { Census } \\
\text { year }\end{array}$} & \multirow{3}{*}{$\begin{array}{l}\text { Number } \\
\text { of towns }\end{array}$} & \multirow{3}{*}{$\begin{array}{c}\text { Total } \\
\text { population }\end{array}$} & \multicolumn{4}{|c|}{ Urban Population } & \multirow{3}{*}{$\begin{array}{c}\text { Annual } \\
\text { exponential } \\
\text { growth rate } \\
\text { (urban) } \\
(\%)\end{array}$} \\
\hline & & & \multirow[b]{2}{*}{ Total } & \multirow{2}{*}{$\begin{array}{l}\text { Percentage } \\
\text { to total state } \\
\text { population }\end{array}$} & \multicolumn{2}{|c|}{ Decennial Growth } & \\
\hline & & & & & Absolute & Percentage & \\
\hline 1941 & 1 & 512,069 & 99,716 & 19.47 & 13,912 & 16.21 & 1.50 \\
\hline 1951 & 1 & 577,635 & 2,862 & 0.50 & $(-) 96,854$ & $(-) 97.13$ & $(-) 35.51$ \\
\hline 1961 & 1 & 780,037 & 67,717 & 8.68 & 64,855 & 2266.07 & 31.64 \\
\hline 1971 & 8 & $1,072,753$ & 141,492 & 13.19 & 73,775 & 108.95 & 7.37 \\
\hline 1981 & 32 & $1,420,953$ & 375,460 & 26.42 & 233,968 & 165.36 & 9.76 \\
\hline 1991 & 31 & $1,837,149$ & 505,645 & 27.52 & 130,185 & 34.67 & 2.98 \\
\hline 2001 & 33 & $2,293,896$ & 575,968 & 25.11 & 70,323 & 13.91 & 1.30 \\
\hline 2011 & 51 & $2,855,744$ & 834,154 & 29.21 & 258,186 & 44.83 & 3.70 \\
\hline
\end{tabular}

Shifting cultivation is prominently practiced by the ethnic groups of Nagas, Kukis, Mizos, Zhomis, etc. [20]. The deforestation for Jhuming (shifting cultivation) is an old practice in the hills of Manipur. During the last 20 years there is a tremendous increase in the area of Jhum cultivation, mostly in the dense forest areas caused by rapid increase of tribal population living in the forests [20]. The total area under shifting cultivation in Manipur was reported to be 85220 ha in 2005 - 2006 and subsequently decline was also reported to be 47163 ha in 2008 - 2009. It was 137970 ha for the period 2014 - 2015 [26]. The shifting cultivation area in the wasteland atlas for the year 2005 - 2006 is 85,220 ha and 2008 - 2009 is 47163 ha and Jhum area for the year 2017 reported by Manipur Remote Sensing Application centre (MARSAC) is found to be $1,22,147$ ha [27].
The data reported exhibits huge variation. Such variation has been reported not only in India but in other countries also [26]. Country by country analysis shows that both area under Swidden and the number of people dependent on Swidden are largely unknown and the data from each country are highly variable [28].

In a study of the extent and dynamics in shifting cultivation (locally called "Jhum") landscapes in North-East India (NEI) particularly in hilly areas of Manipur it was found that on an average, $44-55 \mathrm{~km}^{2}$ of forest was annually slashed for shifting cultivation with Jhum size ranging from 1 ha to 2 ha in Ukhrul and 5 -7.5 ha in Chandel [29].

"Jhuming or shifting cultivation which is being practiced in more than $67 \%$ of the total agricultural land of the hills is not only 
leading to stagnation of agricultural production but also denudation of hill slopes, large scale erosion and loss of fertility. The sharp and steady increase in hill population in last few decades have resulted in intensification of Jhuming practices and its integral component of the wanton destruction of forest to an alarming scale. This has caused heavy degradation of environment and irreparable loss of biodiversity" [30].

One adverse environmental impact of shifting cultivation is that the composition and growth of natural vegetation is declining especially with the trend to reduce the fallow period. Forest fires for Jhuming purposes are causing destruction of flora and fauna of the forest ecosystem. Sheet, rill and full erosion happens due to high intensity rainfall just after clearing the land. There is denudation of rivers and lakes in the valley by the soil particles brought down from the hills due to large scale soil erosion caused by Jhum cultivation. Inundation of low laying areas and flash flood during the rainy season has become annual feature in the valley due to rising river bed in all the rivers in Imphal Valley [31]. There is also diminished availability of water, and the length of the dry period increasing in the local streams and springs supplying drinking water [32].

Recent analyses of the issue have shown that traditional shifting cultivation (long cycle $>10$ years), generally prevalent in places where population densities are low and in remote places, appears to be good as it provides food security and livelihood without causing any significant degradation of land. However, the distorted shifting cultivation (short cycle $<5$ years), a consequence of increasing land use pressure, is not good land use and therefore requires to be transformed [33].

\section{Large scale development projects (dam, industries etc.)}

The Ithai barrage on the Manipur river was constructed in 1979 as a part of the national Loktak multipurpose hydroelectric project.
"Few cases better illustrate the varied and often disastrous consequences that the construction of dams have than the Ithai barrage on the Manipur river. The construction of this dam has had a devastating effect on the Loktak wetland and the people dependent on it for their sustenance" [34]. Due to the commissioning of Loktak project by the National Hydro-Electric Power Corporation (NHPC) in 1983, the level of water has been raised to $769 \mathrm{~m}$ permanently with the help of the Ithai barrage for generating electricity. "This dam has "permanently" raised the water level of this wetland and has blocked the natural flow of water to and/or from the wetland, severely altering the hydrologic cycle of a delicately balanced system" [34]. Changes to the floating Phumdi have led to the endangering of native aquatic vegetation, extinction of native fish species, thinning and proliferation of the Phumdi. Schemes have been taken up for clearing the Phumdi and yet things move at a slow pace and the Phumdi still proliferate.

Regarding the Ithai barrage, heavy inundation of water caused by it has dispossessed many marginal farmers of their main means of earning. It has submerged between 20,000 to 83,000 ha of cultivable lands. "The government's estimate of 20,000 "ha" is widely held to be an understatement" [35]. With their lands submerged by the project, many people changed their occupation from soil tilling to fishing. This increasing population now dependent on fisheries has created an additional demand on already depleted resources. There is still ongoing public debate about the pros and cons of Tipaimukh project, and the project has still not started because of public objections because of its environmental consequences as vast tracts of land are going to be submerged. The Mapithel Dam (The Thoubal River Valley Multipurpose Project) of Thoubal has already submerged large tracts of agricultural lands, gazing grounds and forest areas and have inundated villages [36]. 


\section{SOME MAN-CREATED ENVIRONMENTAL HAZARDS IN MANIPUR}

\section{Wastes generation}

The quantity of solid wastes generated in greater Imphal including Municipal Area is to the extent of $125 \mathrm{Mt}$ to $160 \mathrm{Mt}$ a day and biochemical wastes of $672 \mathrm{~kg} /$ day to $1134 \mathrm{~kg} /$ day in the observed area. There is trash, garbage, biomedical wastes from health centres/hospitals etc. This is a visible threat to the quality of life and "they are happy breeding ground of undeclared diseases" [31]. Clogging of drains by rubbish causes water stagnation and mosquito menace. Roads and market areas are littered with smelly rubbish and trash heaps. There is no viable method of waste disposal and recycling/reuse of waste. There is also no requisite expertise for municipal solid waste management in the MAHUD directorate which controls 28 local urban bodies at present. There is no permanent dumping site/treatment plant for $\mathrm{MSW}$ at present [31].

\section{Air pollution generation}

Another threat to human development is the effect on health of air pollution generated in Manipur. Rapid growth of human population intensifies air pollution. It is exacerbated by the increase in the number of vehicles plying on the roads. The number of automobiles, of trucks, car and taxis, (during 1973 - 2004) increased 8, 28 \& 36 times respectively, whereas that of more polluting 2 -wheelers galloped 161 times. $86 \%$ of civilian vehicles registered in Manipur remain concentrated in Imphal East \& Imphal West districts with a mere total area of $1228 \mathrm{~km}^{2}$. In fact, the number of vehicles registered in Manipur is 146,730 as on $31^{\text {st }}$ March, 2008 [31]. The total vehicle population of Manipur as on December 2017 has increased to 367,035 [37]. Another problem is the continuous increase in construction activities. Dust from such construction clogs the airs and makes breathing difficult especially for people with asthma related ailments. Last but not the least, there is lack of civic sense of the people in Manipur who routinely burn waste products as a form of disposal, including plastic and polythene bags which would have adverse consequences for health.

\section{Water pollution}

As an example of water pollution, Nambul River (a river in the heart of Imphal, the capital of Manipur) has turned into a big, stagnant and highly polluted nallah (drain). Water pollution is caused mainly by unplanned expansion of urban areas, inadequate drainage system and lack of adequate sanitation and other basic amenities, untreated sewage running directly into water bodies, run-offs lashed with a variety of agro-chemicals from agricultural fields finding way to the drainage system, especially during rainy season, leaching into the soil of the residues of chemical fertilizers, pesticides, herbicides etc., which is harmful to aquatic plants and animals and ultimately to human beings, use of chemicals for catching fish etc. At Loktak Lake, the increasing number of Phum dwellers has defiled the waters with faecal matter and domestic waste (number of dwelling huts on Phums increased from 4 in 1960 to 966 by 2001). The possibility of surface water at Lamphelpat being contaminated with biomedical waste, particularly during rainy season is very high [16].

Even drinking water supplied by public authorities is polluted in Manipur. According to NFHS-3, $52 \%$ of households in Manipur use an improved source of drinking water (60 $\%$ of urban households and $48 \%$ of rural households) but only $12 \%$ (27\% urban and 5 $\%$ rural) have drinking water piped into their dwelling, yard, or plot. In addition, $21 \%$ of households get their drinking water from a public tap or standpipe. $85 \%$ of households treat their drinking water to make it potable: two-thirds boil the water $(67 \%), 15 \%$ use a water filter and the remaining, strain the water through a cloth or treat it in some other way [38]. Percentage of households with an improved source of drinking water is now only 
$41.6 \%$ in 2015 - 2016 according to NFHS-4 [39].

\section{Shrinking forest cover, destruction of natural habitat and biodiversity}

Out of 126 species of bamboos reported in India, 53 species are found in Manipur. Teak, Pine, Oak, Uningthou (Phoebe spp.) Leihao (Michelia spp.) are the major species growing in Manipur [14]. During a period of 6 years the total area of dense and open forest in Manipur has decreased from $17,621 \mathrm{~km}^{2}$ in 1995 to 16,926 in 2001. It has now decreased to $16,847 \mathrm{~km}^{2}$ in 2019 . The reserved forest area is fixed only at $8.6 \%$ of the total forest area, i.e. $1,467 \mathrm{~km}^{2}$. Recorded forest area (RFA) in the state is $17,418 \mathrm{~km}^{2}$ of which $1,467 \mathrm{~km}^{2}$ is reserved forest, $4,171 \mathrm{~km}^{2}$ is protected forest and $11,780 \mathrm{~km}^{2}$ is unclassified forests. In Manipur, during the period $1^{\text {st }}$ January 2015 to $5^{\text {th }}$ February 2019, a total of 263.20 ha of forest land was diverted for non-forestry purposes under the Forest Conservation Act, 1980. As per the information received from the state during that last two years, 11,346 ha of plantations were raised in the state [14].

As deforestation continues, many forest areas have become barren and unproductive. Certain areas of hill districts, once with rich vegetation, are now transformed to rocky structures. In Manipur, the massive deforestation has resulted in the loss of about 20 ha of forest cover a day [16]. According to the Forest Survey of India, the various reasons for the fast removal of the forests in the state are "burning" of the forest $(99 \%)$ due to Shifting cultivation (Jhuming practice) and hunting of animals whereas felling of trees by the local people for fuel wood hardly constitute $1 \%$ of forest removal in the state [40]. Forests are being cleared for housing and agricultural purposes and there is illegal occupation even in reserved areas. There is high population pressure, excessive deforestation for firewood and timber, occurrence of forest fires, encroachment of land for developmental works like establishment of housing colony, road and dam construction etc. which are also responsible for forest loss. Commercial exploitation of forest plants and animals is another common phenomenon prevailing in this state, "Many timber species and commercially important plants like Agar, Cinnamonum, Smilax etc, and animals like Malayan Sun bear, Pangolin etc. are constantly exploited for commercial purpose" [16]. The excessive use of chemical fertilizers, pesticides, herbicides etc. also causes a great danger to our biodiversity, particularly to microbes and aquatic plants and animals [16]. Overexploitation of forest resources without proper scientific management for sustainability is ultimately going to lead to extinction of various flora and fauna.

There is also increase in the rate of siltation and frequent landslides due to the destruction of the forest ecosystem in the region which causes great misery to the general people of Manipur. Manipur witnessed six major landslides in 2018, three in 2017, one in 2015 and four in 2010 according to data provided by the environment ministry. Many such landslides, road blockage, heavy siltation etc. recur almost every year.

Table 5 gives the change in forest covers and tree cover in Manipur and India from 2001 to 2019. The forest cover of Manipur is more than $70 \%$ of the total geographical area in all the years covered in the forest surveys of India initiated since 1987 by the Ministry of Environment, Forest and Climate Change, India. There are only 15 states with forest cover larger than $33 \%$ of their geographical area with Manipur $5^{\text {th }}$ in rank after Lakshadweep, Mizoram, Andaman and Nicobar Islands, and Arunachal Pradesh with a forest cover of $77.69 \%$ in 2017 assessment. As compared to the 2015 assessment, there has been a positive change percent of 1.18 in 2017 . The change in forest cover with respect to ISFR 2015 is $263 \mathrm{~km}^{2}$ in Manipur. The net increase of $263 \mathrm{~km}^{2}$ observed in the state is due to plantation and conservation as well as regrowth in shifting cultivation [14]. But a negative aspect is that the forest cover of the state has declined by about $2.88 \%$ in 2019 over 2017 as shown by the table. 
Table 5. Comparison of the change in forest cover and tree cover in Manipur and India [41]

\begin{tabular}{|c|c|c|c|c|c|c|c|c|}
\hline \multirow{2}{*}{ Year } & \multicolumn{9}{|c|}{ Manipur } & \multicolumn{4}{|c|}{ India } \\
\cline { 2 - 10 } & $\begin{array}{c}\text { Forest } \\
\text { cover } \\
\text { area } \\
\left(\mathrm{km}^{2}\right)\end{array}$ & $\begin{array}{c}\% \\
\text { Change } \\
\text { over past } \\
\text { year }\end{array}$ & $\begin{array}{c}\text { \%of } \\
\text { Geographical } \\
\text { Area }\end{array}$ & $\begin{array}{c}\text { Tree } \\
\text { cover } \\
\text { area } \\
\left(\mathrm{km}^{2}\right)\end{array}$ & $\begin{array}{c}\text { Forest } \\
\text { cover } \\
\text { area } \\
\left(\mathrm{km}^{2}\right)\end{array}$ & $\begin{array}{c}\text { C } \\
\text { Change } \\
\text { over past } \\
\text { year }\end{array}$ & $\begin{array}{c}\text { \% of } \\
\text { Geographical } \\
\text { Area }\end{array}$ & $\begin{array}{c}\text { Tree } \\
\text { cover } \\
\text { area } \\
\left(\mathrm{km}^{2}\right)\end{array}$ \\
\hline 2001 & 16,926 & - & 75.81 & 95 & 675,538 & - & 20.55 & 81,472 \\
\hline 2003 & 17,259 & 1.96 & 77.30 & 136 & 678,333 & 0.4 & 20.64 & 99,896 \\
\hline 2005 & 17,086 & -1.00 & 76.53 & 142 & 690,171 & 1.7 & 20.99 & 91,663 \\
\hline 2007 & 17,280 & 1.13 & 77.39 & 197 & 692,394 & 0.3 & 21.06 & 92,769 \\
\hline 2009 & 17,090 & -1.11 & 76.54 & 193 & 692,027 & -0.1 & 21.05 & 90,844 \\
\hline 2011 & 16,990 & -0.58 & 76.10 & 224 & 697,898 & 0.8 & 21.23 & 91,267 \\
\hline 2015 & 17,083 & -0.54 & 76.51 & 243 & 701,495 & 0.5 & 21.34 & 92,571 \\
\hline 2017 & 17,346 & 1.53 & 77.69 & 220 & 708,273 & 1.0 & 21.54 & 93,895 \\
\hline 2019 & 16,847 & -2.88 & 75.46 & 173 & 712,249 & 0.56 & 21.67 & 95,027 \\
\hline
\end{tabular}

\section{Lakes and rivers}

In the state there were about 500 lakes in the valley in the beginning of the $20^{\text {th }}$ century. Now heavy siltation brought down by rivers have converted many such small lakes into agricultural land. Highly degraded lakes in the state are Kharungphat, Khoidumpat, Pumlen, Loukoipat, Sanapat, Yaralpat and Poiroupat [16]. The water quality of the largest fresh water lake of Manipur, the Loktak Lake is also declining. Population of 0.28 million people living within Nambul river (passing through the heart of Imphal City) catchments generates 72.23 million $\mathrm{t}$ of solid waste and $31.207 \mathrm{~m}^{3}$ of sewage daily. Nambul also, therefore, contributes 4.9 million $\mathrm{t}$ of solid waste and $2,121 \mathrm{~m}^{3}$ of sewage annually into the lake. All the wastes directly or indirectly find their way into Loktak Lake [16]. Pollution of water bodies ultimately will exterminate fishes and other aquatic biodiversity. "Reduction of lakes from 500 to 55 and deterioration of water- quality and river-system may lead us to a new dead end of development interventions." [16].

\section{Land degradation}

Land is degraded when it suffers a loss of intrinsic qualities, decline in its capabilities or loss in its productive capacity. Land degradation may be due to natural causes or human causes or it may be due to combination of both. Soil erosion is the major cause of land degradation [42]. Soil erosion caused by the continuation of Jhum is given below [16, 27]:

- first year of Jhum - $146.6 \mathrm{t} / \mathrm{ha} / \mathrm{year}$,

- second year of Jhum - $170.2 \mathrm{t} / \mathrm{ha} /$ year, and

- abandoned Jhum - 30.2 t/ha/year.

State-wise information on degraded land of the valley districts of Manipur are given in Table 6.

Table 6. State-wise information on degraded land of the district (up to March 2018) [43]

\begin{tabular}{|c|c|c|c|c|c|}
\hline Sl. No. & State/UT & District & $\begin{array}{l}\text { Total area } \\
\text { (ha) }\end{array}$ & $\begin{array}{l}\text { Total degraded } \\
\text { land area (ha) }\end{array}$ & $\begin{array}{c}\% \\
\text { Degraded } \\
\text { land area }\end{array}$ \\
\hline \multirow{2}{*}{1} & \multirow{2}{*}{ Manipur } & 1. East Imphal & 57,800 & 10,238 & 17.71 \\
\hline & & 2. West Imphal & 51,900 & 15,098 & 29.09 \\
\hline & & $\begin{array}{c}\text { Total of affected } \\
\text { districts }\end{array}$ & 109,700 & 25,336 & 23.10 \\
\hline 2. & India & 82 Districts & $328,746,900$ & $8,853,262$ & 2.69 \\
\hline
\end{tabular}


The above table shows that as much as 29.09 $\%$ of total land area is degraded land in Imphal - West district alone. "A major share of soil degradation is caused by chemical deterioration by way of acidification, loss of nutrients and organic matter in combination with water erosion and removal of top soil" [44].

Manipur has 1,768,000 ha degraded and wastelands, which is very high, around $79 \%$ of TGA (Total geographical area) of the state. Soil acidity and soil loss due to water erosion remain the major degradation processes. About $72 \%$ of the state is affected by soil acidity $(1,597,000 \mathrm{ha})$ and $6.7 \%$ is affected by water erosion, accounting for 150,000 ha. Among districts, Churachandpur has highest area under water erosion (33,000 ha), followed by Ukhrul (29,000 ha), Senapati (28,000 ha) and Tamenglong (24,000 ha). Total degraded and wastelands area also follows the same order of districts [45].

"Increasing urbanisation and choking of basins in the valley due to the high pressure on land, unabated deforestation and shortening of Jhum cycles are some of the factors responsible for the degradation of the production base (soil, water, vegetation). The severity of soil erosion in the state is very acute and has indeed reached alarming proportions. It is estimated that about $60 \%$ of the TGA is degraded." [44].

\section{Menace of plastic bags}

Plastic/polythene bags also seriously pollute the environment. People discard them along with other rubbish or just burn them along with other wastes. There seems to be no one to collect the rubbish and carry it away to a more appropriate place; and there is no one to collect the plastic bags for recycling. When plastic is burned, it emits dangerous carcinogenic products like dioxin, but burning of waste products including plastic is the common norm in Manipur.

\section{SOME POSITIVE STEPS TAKEN UP}

The foundation stone of a solid waste treatment plant has been laid at Lamdeng on February 6, 2009, with components of segregation, recycling, composting \& land fill. Incinerator installed one each at RIMS, Lamphel and Shija Hospital, Langol to deal with the combustible component of biomedical waste.

\section{CONCLUSION}

Some points that can be drawn from the study:

- Given the rich resource endowment of Manipur specifically with reference to its medicinal plants, which might be destroyed due to increasing urbanization and habitat destruction, there is a need for patenting the products and applying for GI tags to preserve the products and its derivatives for posterity and put the state on the world map for such products.

- Manipur has also experienced global warming and climate change. There is need to evolve strategies for combating its effects.

- A proper environmental impact assessment has to be done before implementing a project like construction of a dam for a multipurpose river valley project.

- We are losing our forest cover because of the needs generated by excessive population pressure and agricultural needs. Here measures of population control are also needed.

- Land degradation has to be checked by afforestation programmes, (i.e., by planting trees), by proper management of wastelands, by transforming shifting agriculture practices especially in areas where there is tendency to reduce the fallow period to less than five years, etc.

- Urban planning has to be done properly. Proper waste disposal system, proper drainage system, and developing 
conservation methods of rain water during rainy season for use during the dry season are also necessary. Studies need to be done on methods of waste segregation and disposal. Measures to check air and water pollution have to be taken.

- Projects for reclamation of wasteland can be taken up to turn barren sterile wasteland into something fertile, suitable for habitation and cultivation.

- We need to save the forests and rich abundant resources of the state from the ravages of climate change and concomitant man-made pollution. There is a need for mass awareness campaigns to inform the public about the dangers of our pristine environment decaying and dying because of their own blind ignorant actions and our precious heritage lost forever to time.

- Sustainable development is the current development lexicon; it is not only our needs that matter but that of the future generation that assumes importance. Future should not be allowed to suffer in favour of the present. Temporary and short term gains alone should not matter; future sustainability is important. Protection of our environment, conservation of biodiversity, giving importance to ecological and human considerations in any developmental activity, etc. has acquired a critical significance as the basic foundation of long term sustainable development. So development planning has to be considerate ethical planning for proper design of future development and quality of life. It has to focus on ways and measures of environment protection.

- It is said that there cannot be creation (development) without some destruction, but wanton destruction of our natural resources ultimately will result in depletion of our scarce non-renewable resources.

- There is need to evolve a practical environmental strategy for Manipur that takes care of our bountiful resources and sustain it for future generations, by practicing proper utilisation of natural resources, for conservation and for enhancement of such resources.

- If we do not take care of our environment, the earth, our home is in danger, there is just so much abuse that our planet can take. It is time we put environmental concerns at the centre of our development agenda.

\section{REFERENCES}

[1] Our Common Future, Brundtland Report 1987, Report of the World Commission on Environment and Development, United Nations, 1987.

https://www.are.admin.ch/are/en/home/s ustainable-development/internationalcooperation/2030agenda/un-milestonesin-sustainable-development/1987-brundtland-report.html, Accessed: October 23, 2019.

[2] K. Singh, Sustainable Development: Some Reflections, Indian Journal of Agricultural Economics 54(1999) 1, 641.

[3] Government of India, Compendium of Environment Statistics 2016, Ministry of Statistics and Programme Implementation, Central Statistics Office, Social Statistics Division, 2017. http://mospi.nic.in/publication/compendi um-environment-statistics-2016, Accessed: August 22, 2019

[4] P. Pandey, Environment and Human Development (A summary of different articles on the environment and human development), 2009.

https://www.scribd.com/doc/19255785/E nvironment-and-Human-Development, Accessed: May 15, 2010.

[5] Sangai Population Up, The Hindu, May 14, 2016.

https://www.thehindu.com/todayspaper/tp-national/tp-otherstates/sangaipopulation-up/article8597904.ece, Accessed: January 13, 2019.

[6] H.B. Singh, R.S. Singh, J.S. Sandhu, Herbal Medicine of Manipur A Colour 
Encyclopaedia, $1^{\text {st }}$ Edition, Daya Publishing House, Delhi, India, 2003.

[7] A. Premila Devi, Plants used by Meitei Community of Manipur for the Treatment of Diabetes, Assam University Journal of Science \& Technology: Biological and Environmental Sciences 7(2011) I, 6366.

[8] M.H. Khan, P.S. Yadav, Ethno Medical Plants of Manipur, North-East India (Thoubal District), $1^{\text {st }}$ Edition, M/s Bishen Singh Mahendra Pal Singh, Uttarakhand, Dehradun, India, 2014.

[9] R. Athokpam, M. Bawari, M.D. Choudhury, A Review on Medicinal Plants of Manipur with special reference to hepatoprotection, International Journal of Advances in Pharmaceutical Research 5(2014) 3, 182-191.

[10] S. Leishangthem, L.D. Sharma, Study of Some Important Medicinal Plants found in Imphal-East District, Manipur, India, International Journal of Scientific and Research Publications, 4(2014) 9. http://www.ijsrp.org/research-paper0914/ijsrp-p33109.pdf, Accessed: September 1, 2019.

[11] T. Inaocha Devi, K. Ujala Devi, E.J Singh, Wild Medicinal Plants in the Hill of Manipur, India: A Traditional Therapeutic Potential, International Journal of Scientific and Research Publications $\quad$ 5(2015) 6. http://www.ijsrp.org/research-paper0615/ijsrp-p4239.pdf, Accessed: September 21, 2019.

[12] Y. Khoirom Devi, H. Maibam Devi, K. Potsangbam Singh, Survey of Medicinal Plants in Bishnupur District, Manipur, North Eastern India, International Journal of Applied Research 3(2017) 4, 462-471.

[13] R. Panmei, P.R. Gajurel, B. Singh, Ethnobotany of medicinal plants used by the Zeliangrong ethnic group of Manipur, Northeast India, Journal of Ethnopharmacology 235(2019), 164 182.

[14] State of Forest report 2019, Forest Survey of India, Ministry of
Environment, Forest and Climate Change, 2019. http://fsi.nic.in/isfr19/vol2/isfr-2019-volii-manipur.pdf, Accessed: September 12, 2019.

[15] A.K. Phurailatpam, S.R. Singh, R. Nongthombam, Conservation of medicinally important plants by the indigenous people of Manipur (Meiteis) by incorporating them with religion and nature worship, Current Science 109(2015) 1, 25-30.

[16] State of Environment Report Manipur, Environment and Ecology Wing, Government of Manipur. http://manenvis.nic.in/WriteReadData/P ublication/manipur-SoE_0.pdf, Accessed: October 23, 2019.

[17] A. Khumbongmayum, M.L. Khan, R.S. Tripathi, Sacred Groves of Manipurideal Centers of Biodiversity Conservation, Current Science 87(2004) 4, 430-433.

[18] Manipur State Action Plan on Climate Change 2013, Directorate of Environment, Government of Manipur, 2014.

http://www.indiaenvironmentportal.org.i n/files/file/manipur\%20state\%20action\% 20plan\%20on\%20climate.pdf, Accessed: January 10, 2020.

[19] P. Koijam, J. Yumnam, Climate Crisis and Indigenous People's Rights in Manipur, Centre for Research and Advocacy, Manipur, 2015.

https://cramanipur.files.wordpress.com/2 015/10/climate-change-and-ip-rightsmanipur_sept-15.pdf, Accessed: January 6, 2019.

[20] M. Reimeingam, Shifting cultivation in Manipur: Land, Labour and Environment, Journal of Rural Development 36(2017)1, 97-119.

[21] Directorate of Economics \& Statistics, Land Use Statistics at a glance 1999 2000 to 2008 - 09, Department of Agriculture \& Cooperation, Ministry of Agriculture, Government of India, New Delhi, 2010. https://eands.dacnet.nic.in/LUS-200809.htm, Accessed: December 10, 2019. 
[22] Directorate of Economics and Statistics, Land Use Statistics at a Glance 2005 06 to 2014 - 15, Department of Agriculture, Co-operation and Farmer's Welfare, Ministry of Agriculture and Farmer's welfare, Government of India, New Delhi, 2016.

https://eands.dacnet.nic.in/LUS_1999_2 004.htm, Accessed: December 10, 2019.

[23] Government of Manipur, Statistical Handbook of Manipur 2017, Directorate of Economics and Statistics, Government of Manipur, 2017.

http://desmanipur.gov.in/files/NewsFiles /26Oct2017020620STATISTICAL\%20 HANDBOOK\%20of\%20Manipur\%2020 17.pdf, Accessed: January 25, 2020.

[24] Government of Manipur, Economic Survey Manipur 2013 - 14, Directorate of Economics and Statistics, Government of Manipur, 2014. http://desmanipur.gov.in/files/NewsFiles /26Jun2015121318Economics\%20Surve y2013-14.pdf, Accessed: January 25, 2020.

[25] Government of India, Selected Socioeconomic Statistics India, Ministry of Planning and Programme Implementation, Centrals Statistics Office, Social Statistics Division, 2017. http://mospi.nic.in/sites/default/files/publ ication_reports/SelectedSocio-

EconomicStatisticsIndia2017_27oct17.p df, Accessed: January 10, 2020.

[26] P. Punitha, M.A. Ansari, D.K. Pandey, D. Ram, S. Datt, P.K. Sharma, M. Aheibam, S.S.P. Jyothi, N. Prakash, Shifting cultivation in North East India: Social dimension, cross cultural reflection and strategies for improvement, Indian Journal of Agricultural Sciences 88(2018) 6, 811819.

[27] Jhum Improvement for Sustaining Farm Livelihood and Natural Resource Conservation in North Eastern Hill Region: Vistas and Frontiers, Indian Council of Agricultural Research, ICAR Research Complex for NEH Region, Meghalaya, India, 2017. https://krishi.icar.gov.in/jspui/bitstream/ $\underline{123456789 / 10233 / 1 / J h u m \% 20 P u b l i c a t i o}$ n.pdf, Accessed: January 21, 2020.

[28] O. Mertz, C. Padoch, J. Fox, R.A. Cramb, S.J. Leisz, N.T. Lam, T.D. Vien, Swidden Change in Southeast Asia: Understanding Causes and Consequences, Human Ecology 37(2009) 3, 259-264.

[29] P. Thong, U.K. Sahoo, R. Pebam, U. Thangjam, Spatial and Temporal Dynamics of Shifting Cultivation in Manipur, Northeast India based on timeseries satellite data, Remote Sensing Applications: Society and Environment 14(2019), 126-137.

[30] J.K. Singh, An account of the Natural Resources of Manipur: Management and Sustainability Issues, in: Challenges of Economic Policy in Manipur - Essays in honour of Prof M. Iboton Singh, ed. E. Bijoykumar Singh, K. Jhaljit Singh, VolI, $1^{\text {st }}$ edition, Akansha Publishing House, New Delhi, India, 2009, 163-205.

[31] Government of Manipur, State of Environment Report, 2006, Environment and Ecology Wing, 2006. http://www.manenvis.nic.in/soer.htm, Accessed: May 15, 2010.

[32] S.B. Singh, S.V. Ngachan, I.M. Singh, Shifting Cultivation System in Manipur: Some Policy Issues, in: Challenges of Economic Policy in Manipur- Essays in honour of Prof M. Iboton Singh, ed. E. Bijoykumar Singh, K. Jhaljit Singh, VolI, $1^{\text {st }}$ edition, Akansha Publishing House, New Delhi, India, 2009, 260-261.

[33] Cultivation: Towards a Transformational Approach, Report of Working Group III, Nita Aayog, Shifting, 2018. https://niti.gov.in/writereaddata/files/doc ument_publication/doc3.pdf, Accessed: January 12, 2020.

[34] R. Wangkheirakpam, Lessons from Loktak, The Ecologist Asia 11(2003) 1, 19-24.

[35] T. Bijoykumar Singh, The Loktak: The Mirror of Manipur, 2009. http://www.indianfolklore.org/journals/i ndex.php/Ish/article/download/322/349, Accessed: April 3, 2010. 
[36] N. Kipgen, Dissenting Voices from the Margins Mapithel Dam in Manipur, 2019.

https://www.epw.in/journal/2015/39/rep orts-states-web-exclusives/dissentingvoices-margins.html, Accessed: January 13, 2020.

[37] Eastern Mirror, January 14, 2020. https://www.easternmirrornagaland.com/ 367035-vehicles-registered-in-manipurtill-dec-2017/, Accessed: January 10, 2020.

[38] National Family Health 2005 - 06 Survey (NFHS-3) India, Manipur, Ministry of Health and Family Welfare, Government of India, 2008. http://rchiips.org/NFHS/NFHS3\%20Data/Manipur_report.pdf,

Accessed: March 21, 2019.

[39] National Health survey 4, State Fact Sheet, Manipur, Ministry of Health and Family Welfare, Government of India, 2016. http://rchiips.org/NFHS/pdf/NFHS4/MN FactSheet.pdf, Accessed: January 21, 2020.

[40] B.M. Sharma, Impact of Environmental Upheavals in Manipur, in: Constraints in development of Manipur, ed. C.J. Thomas, R. Gopalakrishnan, R.K. Ranjan Singh, $1^{\text {st }}$ Edition, Regency Publications, New Delhi, India, 106-112.

[41] Forest Survey of India, Ministry of Environment, Forest and Climate Change. http://fsi.nic.in/forest-report2019, Accessed: September 10, 2019.

[42] Government of India, Compendium of Environment Statistics India 2008-2009, Ministry of Planning and Programme Implementation, Centrals Statistics Office, Social Statistics Division, 2010. http://mospi.nic.in/publication/compendi um-environment-statistics-2008-2009,

Accessed: August 12, 2019.

[43] Government of India, EnviStats India 2019 (Vol. I, Environment Statistics), Ministry of Statistics and Programme Implementation, Government of India, 2019.

http://www.mospi.gov.in/publication/env istats-india-2019-voli-environmentstatistics, Accessed: January 19, 2020.

[44] Institute for Human Development, Manipur State Development Report, New Delhi, Planning Commission, Government of India ,2006.

http://manipur.nic.in/planning/DraftMS DR/Default_DraftMSDR.htm, Accessed: July 20, 2010.

[45] Degraded and Wastelands of India Status and Spatial distribution, Indian Council of Agricultural Research (ICAR) and National Academy of Agricultural sciences, New Delhi, 2010. https://icar.org.in/files/Degraded-andWastelands.pdf, Accessed: December $12,2019$. 